retinoblastoma. $\mathrm{Li}$ and $\mathrm{Jaffe}^{20}$ reported on 46 patients who produced 107 pregnancies after treatment for malignant disease in childhood. There was no increase in abortions, stillbirths, cancer, or major chronic disease in the offspring. Possibly early death of an embryo might have passed unnoticed; recessive mutation would not be detectable in such a study.

We need long-term prospective studies of gonadal function and sexual development in children treated for cancer. The risk of permanent gonadal damage should be definable in both sexes in relation to the intensity of treatment and the age at the start. The collaborative follow-up study of childhood cancer survivors in Britain being organised by the Childhood Cancer Research Group ${ }^{21}$ should make such investigations easier to arrange.

${ }^{1}$ Himelstein-Braw, R, Peters, H, and Faber, M, British fournal of Cancer, $1977,36,269$.

${ }^{2}$ Himelstein-Braw, R, Peters, H, and Faber, M, Acta Radiologica (Therapy), 1978 , in press.

3 Shalet, S M, et al, British fournal of Cancer, 1976, 33, 655.

${ }^{4}$ Sherins, R J, Olweny, C L M, and Ziegler, J L, New England fournal of Medicine, 1978, 299, 12.

5 Lintern-Moore, S, et al, fournal of Reproduction and Fertility, 1974, 39, 53.

6 Valdes-Dapena, M, Annals of the New York Academy of Sciences, 1967, 142, 597.

${ }^{7}$ Peters, H, Himelstein-Braw, R, and Faber, M, Acta Endocrinologica, $1976,82,617$

${ }^{8}$ Ham, A W, Histology, 7th edn, p 904. London, Philadelphia, Lippincott, 1974

9 Baker, J W, et al, Lancet, 1972, 1, 1307.

10 Speiser, B, Rubin, P, and Casarett, G, Cancer, 1973, 32, 692.

11 Slanina, T, et al, International fournal of Radiation Oncology, Biology and Physics, 1977, 2, 1.

12 Penny, R, et al, fournal of Clinical Investigation, 1970, 49, 1847.

13 Fairley, K F, Barrie, J U, and Johnson, W, Lancet, 1972, 1, 568.

14 Pennisi, A J, Grushkin, C M, and Lieberman, E, American fournal of Diseases of Children, 1975, 129, 315.

15 Kumar, R, et al, Lancet, 1972, 1, 1212

16 Buchanan, J D, Fairley, K F, and Barrie, J U, Lancet, 1975, 2, 156.

17 Siris, E S, Leventhal, B G, and Vaitukaitis, J L, New England fournal of Medicine, 1976, 294, 1143.

18 Shalet, S M, et al, fournal of Pediatrics, 1977, 90, 920.

19 Holmes, H A, and Holmes, F F, Clinical Pediatrics, 1975, 14, 819.

$20 \mathrm{Li}, \mathrm{F} \mathrm{P}$, and Jaffe, N, Lancet, 1974, 2, 707.

${ }^{21}$ Draper, G L, 1978, personal communication.

\section{Spasmodic torticollis}

"Torticollis," said Kinnier Wilson," "is a mere symptom, and self-evident at that; the term denotes intermittent spasmodic movements of the neck muscles, also tonic attitudes of rotation or tilt." The spasms are either tonic or clonic and are caused by contractions, singly or in combination, of the sternomastoids, trapezii, and splenius capitis. In the nineteenth century Gowers ${ }^{2}$ recognised the occasional case where torticollis spread to facial and arm muscles and noted aching or "neuralgic" pain in severe forms and the hypertrophy of the affected muscles developing from overuse. The condition causes much distress, but medical progress has been disappointing.

It is important-and usually easy-to exclude torticollis secondary to cervical adenitis or other local painful conditions and to recognise torticollis tic, a variant of habit spasm. Despite much controversy, ${ }^{3}$ undoubtedly both hysterical and organic varieties of torticollis occur, but the latter now seems much more common. There are, however, two separate pitfalls-dogmatically ascribing all cases to a restricted localised form of torsion dystonia (dystonia musculorum deformans) and labelling all cases hysterical simply because pathological lesions in the brain are usually absent. Spasmodic torticollis occurred alone or with Parkinsonism in some cases of encephalitis lethargica. Yet good pathological studies have been rare and the best one ${ }^{4}$ found no macroscopic or histological abnormalities. Three earlier reports described bilateral lesions in the putamen, caudate, and pallidum, but their meaning is questionable. ${ }^{4}$ Lesions in the vestibular pathways induce abnormal tonic neck postures in macaques and other primates; lesions in and close to the red nucleus also cause tonic torticollis. ${ }^{5}$ But in man neither section of the eighth nerve nor labyrinthectomy appears to reproduce the clinical disorder. ${ }^{4}$

In a recent study Matthews $\mathrm{et}^{a l^{6}}$ have carefully studied and followed up 30 patients with torticollis. As in other series, women outnumbered men; the peak age of onset was in the fourth and fifth decades; and six patients had additional neurological signs (arm dystonia, writer's cramp, generalised torsion dystonia, essential tremor, and Parkinson's disease). The results of their investigations were essentially negative: electromyographic studies of neck muscle showed variable, inconsistent reflex effects on the spasms when the patient held weights in either hand, closed his eyes, and touched or pressed his face to restrain the movement (antagonistic gesture). Neuro-otological tests showed no vestibular dysfunction. Psychological assessment suggested no deviation from normal in personality before the torticollis developed; but the patients feared ridicule, had marital discord, and were made unhappy by their condition.

The usual natural history ${ }^{7}$ is that the condition progresses for five years, with a chance of remission, and is static for the next five years, with a final stage of late relapse or slow adjustment. In the Oxford series only six of 30 patients had early remissions and four of these later relapsed.

The various medical remedies have in common only their uselessness. Psychotherapy, ECT, phenothiazines, antidepressants, levodopa, and anticholinergics have been tried. Diazepam or haloperidol has given partial relief. These results tend to confirm the organic nature of the disease in most patients, but "cures" and occasional remissions of over 20 years produced by psychotherapy probably underline the conclusion that a few cases have a hysterical origin. Bilateral stereotactic surgery of the thalamus has produced occasional successes, but the results of most such operations have been disappointing. ${ }^{8}$ Anterior cervical rhizotomy, with division of the appropriate spinal accessory nerve, produced satisfactory results in some cases, ${ }^{9}$ but again there were late relapses. Indeed, despite all the recent attempts to clarify its causation and to find suitable treatment, established torticollis still poses intractable problems.

1 Wilson, S A K, Neurology, vol 2, p 1664. London, Arnold, 1940.

2 Gowers, W R, A Manual of Diseases of the Nervous System, vol 2, p 609. London, Churchill, 1888.

${ }^{3}$ Marsden, C D, and Harrison, M J G, Brain, 1974, 97, 793.

4 Tarlov, E, fournal of Neurology, Neurosurgery, and Psychiatry, 1970, 33, 457.

5 Denny-Brown, D, Proceedings of the Royal Society of Medicine, 1962, 55, 527.

${ }^{6}$ Matthews, W B, et al, fournal of Neurology, Neurosurgery, and Psychiatry, $1978,41,485$.

7 Meares, R, Lancet, 1971, 2, 149.

${ }^{8}$ Hankinson, J, in Recent Advances in Neurology and Neuropsychiatry, 8th edn, ed Lord Brain and M Wilkinson, p 147. London, Churchill, 1969.

${ }^{9}$ Northfield, D W C, The Surgery of the Central Nervous System, p 644. Oxford, Blackwell, 1973. 